\title{
INCOME SMOOTHING AND FIRM-SPECIFIC FACTORS: TURKEY CASE
}

\author{
Yetkili Yazar | Correspondent Author: Ömer Faruk \\ BÜYÜKKURT
}

Gelir Yumuşatma ve Firmaya-Özgü Etkenler: Türkiye Örneği

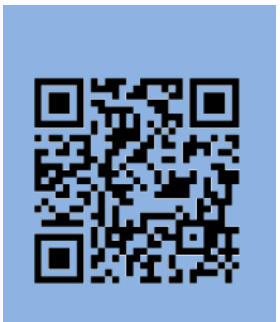

\section{Yazar(lar) | Author(s) \\ Ömer Faruk BÜYÜKKURT $T^{l}$}

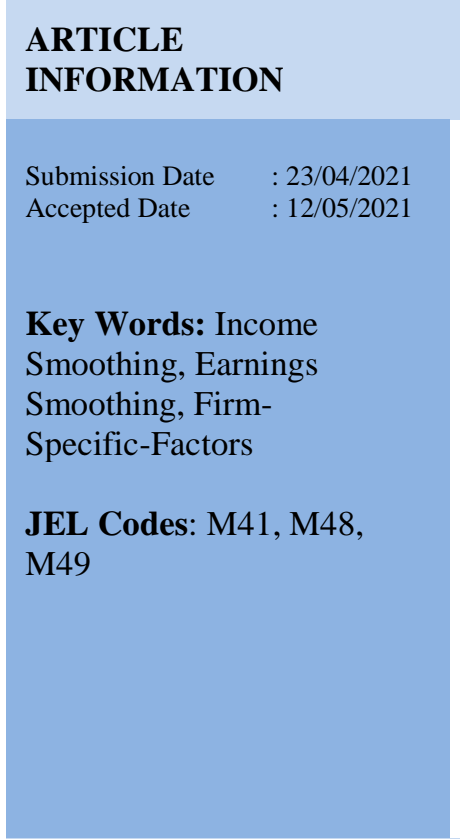

MAKALE BİLGİṠ

Makale Geliş Tarihi : :23/04/2021 Makale Kabul Tarihi : 12/05/2021

Anahtar Kelimeler:

Gelir Yumuşatma, Kazanç

Yumuşatma, Firmaya-

ÖzgüEtkenler

JEL Kodları: M41, M48, M49

This study investigates the income smoothing behaviours of the listed firms in BIST from the period spans from 2012 to 2019. The study scrutinizes such behaviours at the sectoral level. Moreover, the relationship between firm-specific factors -size, leverage, growthand income smoothing practices are also examined. For the detection of theincome smoothing so-called Eckel Model (1981) model is used. Based on the analysis it is found that 1 in 3 observation in the manufacturing sector, 1 in 5 observation in the utility and transportation sector and 1 in 2 observation in the finance sector implement income smoothing practices between the period of 20122019. Regarding firm-specific factors, it is found that compared with the non-smoothing firms, income-smoothing firms are smaller, low leveraged and exhibit lower growth in the manufacturing sector. Moreover, in the finance sector, income- smoothing firms are smaller and low leveraged comparing with the non-smoothing firms. Lastly, there is no significant difference between the income-smoothing and non-smoothing firms with regards to firm-specific factors for the utility \& transportation industry.

\section{ÖZ}

Bu çalışma, BIST'te işlem gören firmanın 2012-2019 dönemini kapsayan gelir yumuşatma davranışlarını incelemektedir. Çalışma, bu tür davranışları sektörel düzeyde irdelemektedir. Ayrıca firmaya-özgü etkenler -büyüklük, kaldıraç, büyüme- ve gelir yumuşatma uygulamaları arasındaki ilişkiler de incelenmiştir. Gelir yumuşatma faaliyetlerinin tespiti için Eckel Modeli (1981) kullanılmıştır. Analize göre 2012-2019 döneminde imalat sektöründe 3 gözlemden l'inin, hizmet ve ulaştırma sektöründe 5 gözlemden 1 'inin ve finans sektöründe 2 gözlemden 1 'inin gelir yumuşatma uyguladığ $\breve{1}_{1}$ kanaatine varılmıştır. Firmaya özgü faktörler dikkate alındığında, gelir yumuşatmayan firmalara kıyasla, imalat sektöründeki gelirlerini yumuşatan firmaların daha küçük, daha düşük kaldıraçlı olduğu ve daha düşük büyüme sergilediği görülmüştür. Bunun yanında, finans sektöründe gelirlerini yumuşatan grupta olan firmaların, yumuşatmayan firmalara göre daha küçük ve düşükkaldıraçlı olduğu ancak daha düşük büyümeye sahip olmadığı gözlemlenmiştir.

\footnotetext{
${ }^{1}$ Öğr. Gör. Dr, Erzincan Binali Yıldırım Üniversitesi İIBF, Bankacılık ve Finans Bölümü, ORCID No:
} https://orcid.org/ 0000-0002-9299-5169, e-posta: faruk.buyukkurt@erzincan.edu.tr

Giresun Üniversitesi İktisadi ve İdari Bilimler Dergisi Cilt: 7, Sayı: 2 Income Smoothing and Firm-Specific Factors: Turkey Case 


\section{Introduction}

Income smoothing is one of the methods that executives implement for the sake of manipulating earnings level in order to avoid earnings fluctuations. The executives try toreduce earnings when the figure is significantly higher than the earnings trend, while theyattempt to increase earnings if it is noteworthily lower than the earnings trend. By doingso, they aim to alleviate volatility in earnings figure. From this point of view, detection of the income smoothing practises of the firms is of vital importance to be able to reliablyextract the real earnings levels from the announced ones. In the same vein, revealing of income smoothing practices of the firms that operate in a specific industry also cruciallyimportant in order to precisely interpret the true performance of that specific sector. In the light of these considerations, this study focuses on the income smoothing practices ofthe listed BIST firms for the period that spans from 2012 to 2019 with a total of 2,069 observations. Apart from the main sample, some sub-samples are also used in the study for the sake of providing in-depth analysis. The sub-samples are created based on the industries, firm-specific factors and smoothing behaviours of the executives of the firms. The industries investigated in this study are manufacturing, utility \& transportation and finance, while the firm-specific factors focused on in this study are firm size, leverage and growth levels of the firms. The so-called Eckel Model (1981) is employed in this study to detect earnings management practices. This model is chosen because of the factthat first, it is simple, and second, its simplicity does not undermine its accuracy. Moreover, the data requirement of the model is not very demanding. Thus, the model is suitable for especially developing stock exchanges in that the number of listed firms is relatively low comparing with developed stock markets. The finding of this study shows that roughly 1 in 3 observation in the manufacturing sector, 1 in 5 observation in the utility and transportation sector and 1 in 2 observation in the finance sector implement income smoothing practices during the investigation period, 2012-2019. Moreover, the income-smoothing firms are smaller, low leveraged and less growing comparing with thenon-smoothing firms in the manufacturing sector. Besides that, income- 
smoothing firmsare smaller and low leveraged comparing with the non-smoothing firms in the finance sector. Lastly, there is no significant difference between the income-smoothing and non-smoothing firms with regards to firm-specific factors for the utility \& transportation industry. The finding of this study can help all interested parties when they are analysingthe BIST firms \& sectors.

The rest of the paper is organized as follows; the next chapter is the literature review, after that the data $\&$ methodology section takes place, following the results $\&$ discussion the conclusion is presented.

\section{Literature Review}

Income smoothing is one of the most preferred methods that managers employ to "adjust" firms' earnings levels. There are various definitions of income smoothing in theaccountancy literature. One of the earliest definition of income smoothing is given by Copeland (1968) together with its must-have characteristics. Copeland (1968) states that income smoothing is “... repetitive selection of accounting measurement or reporting rules in a particular pattern, the effect of which is to report a stream of income with a smaller variation from the trend that would otherwise have appeared". Moreover, he listed the specific characteristics of income smoothing activities. According to Copeland (1968), income smoothing activities must not require further practices in upcoming periods. Secondly, income smoothing activities must be based on "professional judgement" and it must be within the borders of recognized and accepted accounting standards. Thirdly, the practice must result in a significant change in the earnings level. Fourthly, income smoothing practices must not involve operational actions. In other words, this activity must involve the accounting figures only. Lastly, this activity should be used either individually or together with other supporting practices throughout the following periods. Beidleman (1973) describes income smoothing as an executives strategy to suppress the volatility in income. Another historical definition of income smoothing is made by Ronen and Sadan (1981) They asserted that executives employ income smoothing practices to alleviate volatility in earnings so as to makes expected cash flows becomes more predictable. To sum up, as it can be seen from the above definitions, income smoothing is an activity that aims to alleviate the volatility in earnings, practised by the executives in such a way as to obey financial reporting standards. Moreover, this activity is implemented throughout extending periods since the ultimate goal of the strategy is no to deviate from the steadily increasing earnings trend. 
Income smoothing methods are implemented as a result of various motivations. It is stated in the literature that if the executives' compensation payments are subject to longer period performances then those executives are keen on practising income smoothing methods more than the ones that are subject to shorter-term performance results. This might be because of the fact that most of the executives' remunerations are in the type of stock options. So, if the executives smooth the earnings, the reflection of steadily increasing earnings figures on the stock prices might lead them to obtain better bonus payments (Goel and Thakor, 2003 , p.179). Healy (1985, p.105) also connects the income smoothing behaviours of the executives with their bonus plans and states that executives smooth the incomes in the way in which their bonuses becomes higher than itshould have been otherwise. In additions to this, executives also smooth the income in the periods where the earnings are low, in order to secure their jobs. On the other hand, executives also smooth the income in the periods where the earnings are significantly higher than expected, in order to pass the earnings to the upcoming relatively worse periods (DeFond \& Park, 1997, p.117; Fudenberg \& Tirole, 1995, p.77). Moreover, the ownership structure of the firm has also effects on the managers' income smoothing behaviours. If the large institutional owners exist in a firm, then the executives of these firms are less likely to implement income smoothing methods. From this perspective, thissuggestion can be interpreted in a way that, the situation of the non-existence of large institutional owners in a company may play an encouraging role for executives to smoothearnings (Goel and Thakor, 2003, p.180). Tax avoidance is another motivation for executives to smooth income. If the current period's earnings are significantly high, then executives practise income smoothing methods for the sake of reducing income, so as totax, in the current period (Akbari et al., 2019, p.126). To summarize, income smoothing motivations might vary for the firms. Executives compensations, bonus packets, the existence of institutional ownership, tax avoidance are the main motivations that encourage management teams to attempt to smooth the earnings.

Income smoothing can be implemented via two main methods. Since the ultimate aim of the income smoothing is to not deviate from a stably increasing earnings trend, methods of the income smoothing strategy depend on the level of expected net earnings figure. If the earnings figure stays significantly under the historical earnings trend then income boosting methods are implemented for the period. On the contrary, if the earningslevel of the period is substantially above the 
earnings trend, then income decreasing methods are implemented. Thus, there are two scenarios for income smoothing: having inadequate earnings figure or generating too much earning within the current accountingperiod and both scenarios require different income smoothing techniques (Bao \& Bao, 2004). Apart from that, since earnings have two components - cash and accruals- income smoothing strategies theoretically can be implemented through smoothing of either cashflows or accruals.

White et al. (2003, p.60) suggested that income smoothing methods can be groupedinto two sub-categories: intertemporal income smoothing methods and classificatory income smoothing methods. The former one involves adjustment of the timing ofdiscretionary expenditures. If the income is substantially higher than the intended level, then executives, who want to reduce earnings level to achieve stably increasing earningstrend, of the firms shift the discretionary expenditures, such as maintenance, employee training, research and development projects etc, from upcoming periods to the current period. By doing this, a material decrease in earnings is obtained for the current period and the final earnings level becomes close to the aimed earnings trend. On the contrary, if the earnings level is significantly lower than the intended earnings level, the same group of executives shifts the discretionary expenditures from the current period to the upcoming periods. This strategy leads to an increase in earnings in the current period at the expense of the earnings figures of the upcoming period. The latter method involves the manipulation of the classification of economic events in the way in which it serves the purpose of achieving smoothed income trend. For example, if the earnings level of the period is higher than expected, then the doubtful trade receivables can be recorded asbad debts in the current period which causes a reduction in the current period's profit level. On the other hand, if the earnings of the current period is not as high as the targetedlevel, then the executives may reclassify some accounting items for the sake of increase the current period's earnings level. Ibrahim et al. (2020, p.705) made the classification of income smoothing methods as "real income smoothing" and "income smoothing using discretionary accruals". Indeed, their classification covers the same arguments thatexplained above. The concept of "real income smoothing" is similar to "intemporal income smoothing" and "income smoothing using discretionary accruals" is similar to "classificatory income smoothing". The same methods of income smoothing are named in different terms 
by other researchers (Petersen \& Thiagarajan, 2000; Eckel, 1981; Lev \& Kunitzky 1974; Goel \& Thakor, 2003). To sum up, although they are referred to in different terms, essentially there are two major methods for smoothing income. One is smoothing income via discretionary accounting choices, and the other one is smoothing income through operational decisions. Based on the staying above or the below of the earnings trend line executives implement these methods to either reduce or boost the current period's income for the sake of meeting specific earnings targets.

It has been studied in the literature the relations between income smoothing and some firm-specific factors, such as growth, size and leverage of the company. The size ofthe firm can be an explanation for income smoothing since the larger firms are under additional monitoring of analysts (Richardson et al., 2002). This situation might convince executives to obtain steadily increasing earnings trend expectation of the analysts since meeting/beating earnings expectation is a strong motivation for managers. On the other hand, large firms' executives might not blindly desire to significantly excess steadily increasing earnings trend since extreme profit increases may attract governmental and other regulatory bodies' attentions (Watts and Zimmerman, 1990). Thus, they might prefer to push earnings downwardly in case of generating extremely higher profit than expected. When these two arguments are brought together, it can be suggested that the executives of the larger firms may have extra motivation to smooth income comparing with the managers of relatively small firms.

The relation between leverage and income smoothing activities has been studied inthe literature as well. Li \& Richie (2016, p.175) found that the firms that practise more income smoothing strategies enjoy a lower cost of debt. From these results, it might be expected that the executives of the firms that have high leverage rate may perform incomesmoothing activities to lower their cost of debts and by this mean they can lighter the costof the financial burden on the company. Apart from this, although there are some studiesthat have found a positive relationship between in debtedness level and income smoothing practices (Sayunita, 2016) it is not possible to mention that there is a general consensus in the literature regarding this relation. It is documented that executives may be encouraged to increase earnings to avoid breaching debt covenants thus they may prefer to push the earnings upward (Dichev \& Skinner, 2002). On the other hand, debtholders demand managers prepare financial statements in line with conservative accounting principles that 
ultimately result in pushing earnings downward (Bushman \& Piotroski, 2006). However, these opposite forces that aim to increase and decrease earnings respectively, cannot be called income smoothing although the income smoothing practices also aim to increase/decrease earnings. This is because income smoothing is a holistic and uniform strategy that aims to stick to a specific earnings trend. However, upward/downward manipulations of profit figure with the motivation of leverage level are separate strategies and they do not aim to hit one single earnings target. Thus, when the relation between earnings manipulation activities and leverage is studied, the earningsmanagement strategies should not be mistaken for income smoothing. Income smoothing and growth relation have also been investigated before by the researchers. Namazi and Khansalar (2011, p.84) found that growth firms practise significantly more income smoothing methods than value firms. Moreover, Madhogarhia (2009, p.1767) also found that growth firms implement income smoothing activities significantly more than value firms. To sum up, it can be said that the relation between firm-specific characteristics andincome smoothing is investigated by the researchers, yet it is difficult to mention that there is a vast literature on this issue.

\section{Data \& Methodology}

This study uses the data retrieved from the financial statements of the listed BIST firms for the period from 2012 to 2019 (including). The observations belongs to earlier than 2012 was deleted since these periods' data was highly affected by the 2008/09 financial crisis. To be able to make reliable and robust inferences the variables of the study are winsorized at $1 \%$ level and outliers are removed from the sample. Moreover, ifa firm has a missing variable that is used in this study, the whole period is removed fromthe sample. Besides that, after strict data-cleaning procedure, such as deleting observations that presents negative MTB ratios, the final sample is composed of 2,069 firm-years. The data of the study retrieved via Datastream database and the analyses are made via STATA 13 analyser software.

Eckel Model (1981) is one of the mostly used model to identify income smoother companies. This might be because of the simplicity, easyunderstandability of the model.Thus, it is employed Eckel Model (1981) in this study to detect earnings smoothing practices. The model divides the coefficient of variation of the change in income to the coefficient of variation of the change in 
sales, and takes the absolute values of the results. The Eckel Model (1981) is as follows;

$$
\left|C V_{\Delta I}\right|
$$

Where; "CV $C I$ is the coefficient of variation of the change in income and $C V_{\Delta S}$ is thecoefficient of variation of the change in sales" (Eckel, 1981). Based on this model, the observations that have the ratio smaller than 1 but higher than 0 is referred as "Income-Smoother" or "Income-Smoothing" companies.

\section{Results \& Discussion}

Table-1, 2 and 3 present the descriptive statistics, the correlation matrix of the keyvariables and the preliminary findings of the study respectively.

Descriptive Statistics are presented in Table-1. NITAL is the net income of the period divided by the lagged total assets of the firm, MTB is the market-to-book ratio, SIZE is the size of the company obtained via taking natural logarithm of the total assets of the firms, LEVERAGE is the total debt divided by the total assets of the company andfinally descriptive statistics of the so-called Eckel scores of the industries. The average market-to-book ratio, which is frequently used to measure the growth of the firms, is 1.9333 for the whole sample. Moreover, the mean natural logarithm of the observed companies (SIZE) is 12.931. Besides these, the leverage of the sample companies is 0.2417. Mean of the so-called Eckel scores of the manufacturing industry (EckelManu), utility and transportation industry (EckelU\&T) and the finance industries are 1.9933, 2.4670 and 1.2143 respectively. Besides that the Eckel score of the whole sample is 1,8073. Based on the these results it can be said that neither individual industries nor thewhole sample means of Eckel scores are within "income smoother" range model since they are all above 1. the range of These results to some extent do not correspond with thesome of the studies in the literature. This might be the result of strict and rigid data cleaning and winsorization process of the sample before starting to analysing the data. Apart from these, there is no noteworthy and worth-to-mention abnormalities of the rest of the descriptive statistics. 
Table 1. Descriptive Statistics

\begin{tabular}{l|lllll}
\hline Name of Var. & Mean & Stnd. Dev. & Median & $3^{\text {rd }}$ Quartile & $2^{\text {nd }}$ Quartile \\
NITAL & 0.0387 & 0.1193 & 0.0255 & 0.0851 & -0.0096 \\
MTB & 1.9333 & 2.2740 & 1.2000 & 2.0800 & 0.7300 \\
SIZE & 12.931 & 2.2170 & 12.713 & 14.246 & 11.357 \\
LEVERAGE & 0.2417 & 0.2088 & 0.2175 & 0.3752 & 0.0443 \\
Eckel $_{\text {Manu }}$ & 1.9933 & 1.6015 & 1.6145 & 2.8345 & 0.8205 \\
Eckel $_{\text {\&T }}$ & 2.4670 & 1.4496 & 2.5767 & 3.2218 & 1.4736 \\
Eckel $_{\text {Fin }}$ & 1.2143 & 1.4016 & 0.6172 & 1.6778 & 0.2538 \\
Eckel $_{\text {Overall }}$ & 1.8073 & 1.5879 & 1.3514 & 2.6670 & 0.5705 \\
\hline
\end{tabular}

Table-2 exhibits the Spearman correlation matrix of the key variables. IS is the dummy variable and represents whether the firm belongs to income smoother or non- income smoother firm groups. If the Eckel score of a firm is within the range of 0 and 1 based on the Eckel Model, this firm takes the value of 1, otherwise 0 . All other variablesexhibited in Table- 2 are described above. As it can be seen from the table that there is a negative and significant correlation (-0.688) between the Eckel score and IS. This is reasonable since the high Eckel Score makes the firms' income smoothing value in IS is 0 and on the contrary, the low Eckel score makes the firms' income smoothing value in IS is 1. In other words, the Eckel score and IS values inherently greaten in opposite directions. The correlation between IS and firmspecific factors - $\log$ TA, Leverage, MTB

- and the correlation between Eckel score and same firm-specific factors are opposite because of the same reason. As it is shown in the table, the correlations between IS and firm-specific factors are all negative and significant. Although the results represented in this table is not sufficient to make an ultimate inference, the negative and significant correlation between IS and firm-specific factors indicates that such factors have, to some extent, a restrictive effect on income smoothing behaviours of the managers.

Table 2. Spearman Correlation Matrix

\begin{tabular}{l|lllll}
\hline & $I S$ & Eckel & $\log T A$ & Leverage & MTB \\
IS & 1.0000 & & & \\
Eckel & $-0.6889 *$ & 1.0000 & & \\
LegTA & $-0.2767 *$ & $0.2199 *$ & 1.0000 & & \\
MTB & $-0.0978^{*}$ & $0.0833^{*}$ & $0.2317 *$ & 1.0000 & \\
\hline
\end{tabular}

Table-3 compares the quantity and percentage information of the smoother and 
non-smoother firms in the sample. Regardless of the sectors, the overall income smoothers inthe sample account for 38.96 per cent with 806 individual observations. However, number of the non-smoothers is 1,263 , which makes the 61.04 percent of the sample. This indicates that the managers of the Turkish listed firms predominantly not involve in income smoothing activities. When the individual sectors are analysed, it can be seen from the table that finance firms are the ones that smooth their earnings most. Amongst the 539 finance-firm observation, 322 firmyear observation, which accounts for $59.74 \%$ of the whole finance industry in the sample, implemented income smoothing activities. Besides that, the income smoother manufacturing firms correspond to $32.07 \%$ of the manufacturing industry, with 467 firm-years observation. Lastly, comparing with the other two industries, the weight of the income smoother firms in the utility and transportation sector is the lowest with only $22.97 \%$.

Table 3. Income Smoothers and Non-Income Smoothers

\begin{tabular}{|c|c|c|c|c|c|c|}
\hline Variable & $\begin{array}{l}\# \\
\text { Smooth. }\end{array}$ & $\begin{array}{l}\% \\
\text { Smoot. }\end{array}$ & $\begin{array}{l}\# \text { of } \\
S .\end{array}$ & \% of Non-S. & $\begin{array}{l}\text { Total } \\
\text { Observ. }\end{array}$ & $\begin{array}{l}\% \text { of the } \\
\text { Total }\end{array}$ \\
\hline${ }^{I} S_{\text {Manu }}$ & 467 & 32.07 & 989 & 67.93 & 1,456 & 100.00 \\
\hline$I S_{U \& T}$ & 17 & 22.97 & 57 & 77.03 & 74 & 100.00 \\
\hline$I S_{F i n}$ & 322 & 59.74 & 217 & 40.26 & 539 & 100.00 \\
\hline IS Overall & 806 & 38.96 & 1,263 & 61.04 & 2,069 & 100.00 \\
\hline
\end{tabular}

Before exhibiting whether the mean of the firm-specific factors differs with regardsto income smoothing behaviours of the firms, the following figures, Figure1A, 1B and 1C visualize such relationship. The whole sample is split into 10 intervals based on the ranking of the investigated firm-specific factors. In each figure, interval 1 represents the lowest mean value of the firm-specific factor in the sample while interval 10 contains thehighest mean value of the same factor. Figure$1 \mathrm{~A}, 1 \mathrm{~B}$ and $1 \mathrm{C}$ demonstrate the number ofincome smoothers and each bar in each interval shows the number of income-smoother firms corresponds to that interval. Each interval contains 206 firm-year observations. Figure-1A, 1B and 1C exhibit the rankings of the intervals based on size, leverage and growth respectively. Size is measured based on the natural logarithm of total assets, leverage is calculated via the ratio between total debt and total assets and finally, growth is measured ranking of market-to-book ratio.

As it is shown in Figure-1A that the number of the income-smoothers firms is 
the lowest in the interval-10, while the number of income-smoother firm-years is the highest in interval-1. Moreover, the income-smoother firms' number steadily decreases from theinterval-1 to interval-10. Thus, this figure shows a negative relationship between incomesmoothing practices and firm size. In Figure-1B each interval exhibits the number of income-smoother firms with regards to indebtedness level. Similar to Figure-1A, each interval in Figure-1B contains 206 firm-year observations.

Figure 1A

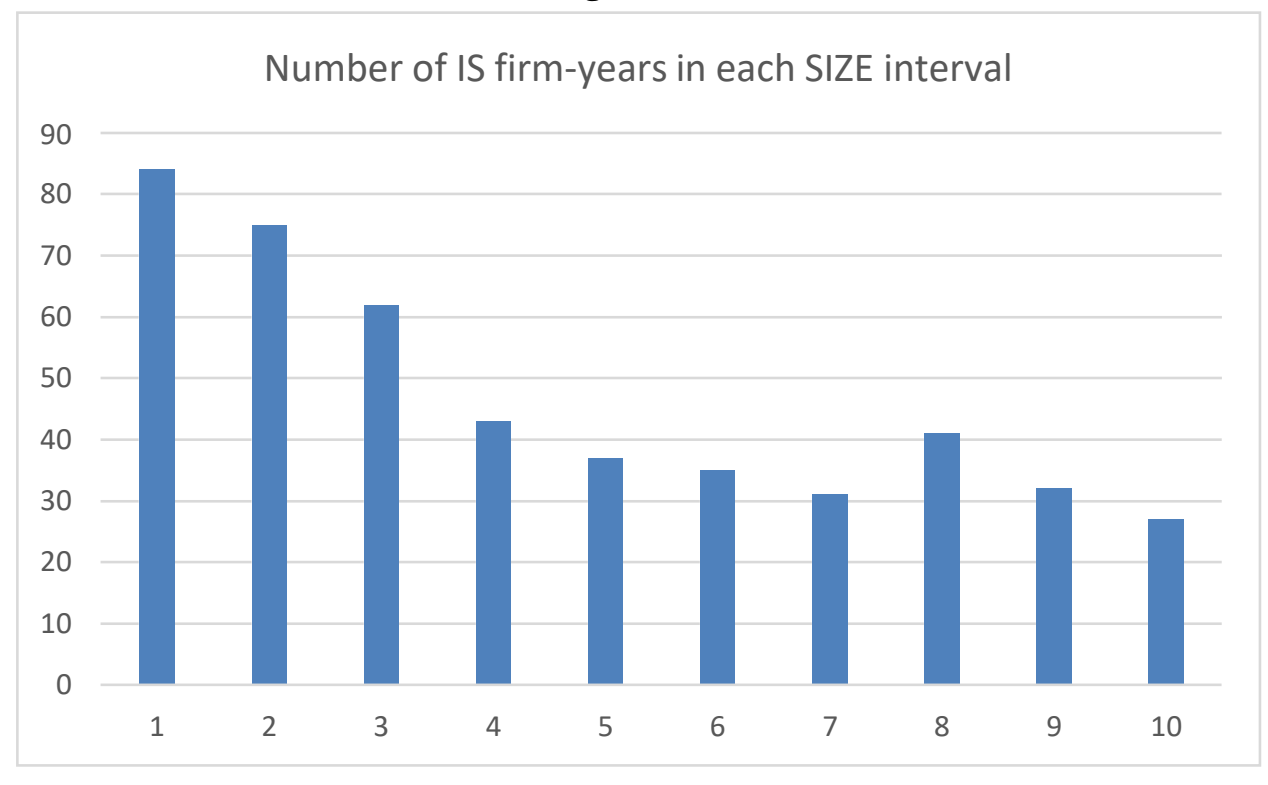

Generally speaking, as it can be seen in Figure-1B, there is a kind of ambiguous negative trend between the leverage and the number of income smoothing firms from interval 1 to interval 7 and after that there is a sharp increase in the number of income- smoothing firms. Apart from this, the number of income smoothing firms, again, higher in interval 1. Although it is not as clear as Figure-1A, it can be said that there is a slightlynegative relationship between the number of income smoothing firms and leverage level. 


\section{Figure 1B}

Number of IS firm-years in each LEVERAGE interval

80

70

60

50

40

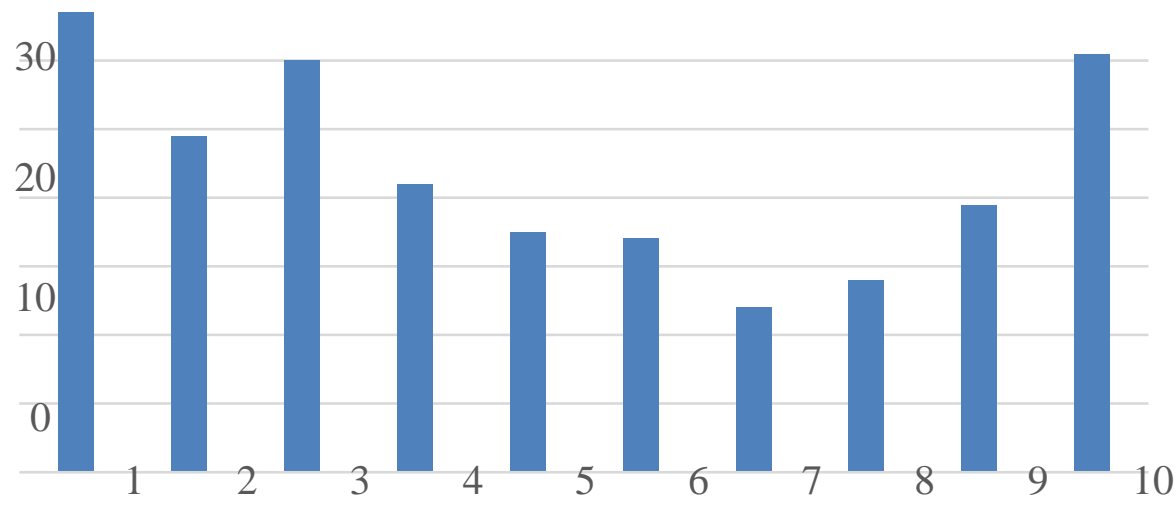

The last figure, Figure-1C, demonstrates the relation between the number of incomesmoothing firms in intervals where each interval contains 206 observations based on their growth level, calculated via MTB values. As it can be seen from the table that it is not possible to claim the existence of any relation between the number of income-smoothingfirms and the growth level since there are continuous ups and downs in the numbers of income smoothing firms from interval 1 to interval 10. 


\section{Figure 1C}

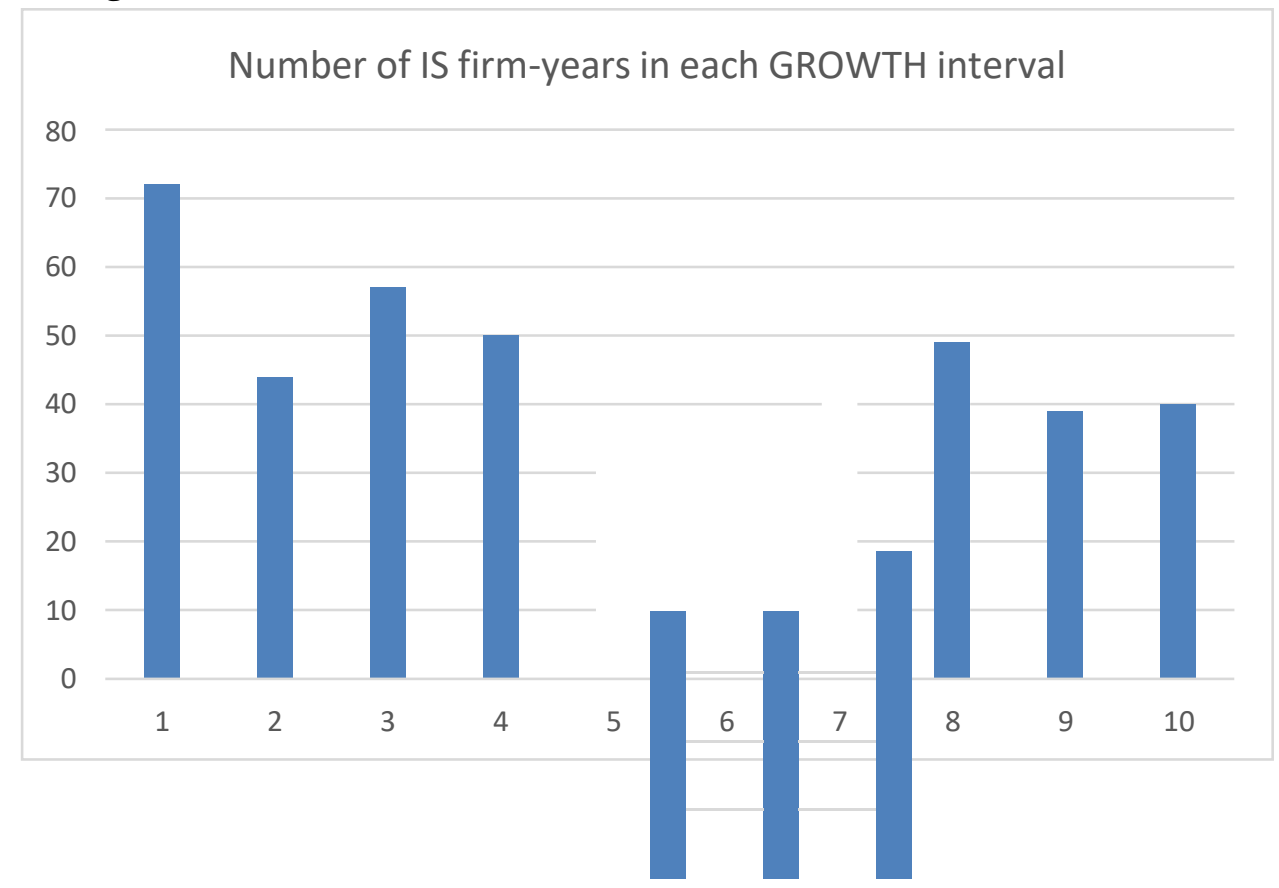

Table-4A, 4B and 4C tabulate the t-test differences in the mean value of income smoothing and non-income smoothing firms' firm-specific characteristics of size, leverage and growth respectively, for each industry.

As it is demonstrated in Table-4A, the mean value of natural logarithm of total assets of income-smoothing manufacturing firms is 12.1239 and it is 13.0186 for non- smoothing firms and the difference in means is statistically significant since the t-test result is 8.6326 . When it comes to utility and transportation industry, the difference in themean value of natural logarithm of total assets between income smoothing and non- income smoothing firms disappears as the means are 14.6325 and 14.0608 respectively and the t-test results is 1.0203 . Finally, the differences in the mean value of natural logarithm of total assets between income smoothing and non-income smoothing firms in finance sector is significant. For the income smoothing firms the mean value is 12.5474 and for the non-smoothing firms it is 14.9077, while the t-test result is 9.9199. Overall, based on the results demonstrated in Table-4A, it can be said that there is a statistically significant difference in firm size between income smoothing firms and non-smoothing firms for manufacturing and finance industry. More specifically, income smoothing firmsin these sectors are significantly smaller than the non-income smoothing firms. This might be because 
of the fact that larger firms are under stronger investigation of governments, they are followed by higher number of analysts and they are also monitoredby public closely than relatively smaller firms (Watts \& Zimmerman, 1990). These reasons might have a discouraging effects on the executives for the implementation of income smoothing activities.

\begin{tabular}{l|llll}
\hline \multicolumn{5}{l}{ Table-4A SIZE } \\
\multicolumn{5}{l}{ A- Manufacturing } \\
\hline \multicolumn{1}{l}{ Group } & Observation & Mean & Std. Error & Std. Dev. \\
\hline Non-smoothing & 981 & 13.0186 & 0.0566 & 1.7750 \\
Smoothing & 439 & 12.1239 & 0.0892 & 1.8703 \\
Diff. bw means & & $0.8947^{* * *}$ & & \\
t-test & & $(8.6326)$ & & \\
\hline B- Utility \& Transportation & & & \\
\hline Group & Observation & Mean & Std. Error & Std. Dev. \\
\hline Non-smoothing & 57 & 14.6325 & 0.2895 & 2.1857 \\
Smoothing & 17 & 14.0608 & 0.3232 & 1.3329 \\
Diff. bw means & & 0.5717 & & \\
t-test & & $(1.0203)$ & & \\
\hline C- Finance & & & & \\
\hline Group & Observation & Mean & Std. Error & Std. Dev. \\
\hline Non-smoothing & 214 & 14.9077 & 0.1822 & 2.6658 \\
Smoothing & 261 & 12.5474 & 0.1552 & 2.5077 \\
Diff. bw means & & $2.3603 * * *$ & & \\
t-test & & $(9.9199)$ & & \\
\hline
\end{tabular}

Table-4B exhibits the mean value differences of indebtedness levels between income smoothing and non-smoothing firms with regard to the industries that firms operate in. The mean value of the indebtedness level of the smoothing and nonsmoothing firms for manufacturing sector is significantly lower for income smoothing firms than non-smoothing firms as the values are 0.2078 and 0.2301 respectively with the t-test results of 2.1302. The results are the similar for the firms from finance sector as the mean values of indebtedness level is 0.1866 and 0.2893 for the income smoothingand non-smoothing firms respectively with the t-test results of 4.3702. Again, there is no significant difference between the mean values of indebtedness levels between income-smoothing and non-smoothing firms of Utility \& Transportation industry as the mean values are 0.5319 and 0.4503 respectively with the t-test result of -1.6416 . 
The final table of the study is Table- $4 \mathrm{C}$, where the differences in the mean valuesof market-to-book ratios between the income-smoothing and non-smoothing firms together with industry classifications. For the manufacturing firms, the mean value of market-to-took ratios of income-smoothing firms is 1.8819 and it is 2.2186 for non- smoothing firms, while the t-test result is 2.3845. Apart from manufacturing sector, there is no significant difference between the mean values of market-to-book ratios between the income-smoothing firms and non-smoothing firms as the t-test results are 0.9486 and -1.2189 for utility \& transportation and finance sectors respectively.

Table-4B LEVERAGE

\begin{tabular}{|c|c|c|c|c|}
\hline \multicolumn{5}{|c|}{ A- Manufacturing } \\
\hline Group & Observation & Mean & Std. Error & Std. Dev. \\
\hline Non-smoothing & 981 & 0.2301 & 0.0055 & 0.1726 \\
\hline Smoothing & 439 & 0.2078 & 0.0096 & 0.2030 \\
\hline Diff. bw means & & $0.0223^{* *}$ & & \\
\hline t-test & & $(2.1302)$ & & \\
\hline \multicolumn{5}{|c|}{ B- Utility \& Transportation } \\
\hline Group & Observation & Mean & Std. Error & Std. Dev. \\
\hline Non-smoothing & 57 & 0.4503 & 0.0238 & 0.1800 \\
\hline Smoothing & 17 & 0.5319 & 0.0434 & 0.1791 \\
\hline Diff. bw means & & -0.0228 & & \\
\hline t-test & & $(-1.6416)$ & & \\
\hline \multicolumn{5}{|l|}{ C- Finance } \\
\hline Group & Observation & Mean & Std. Error & Std. Dev. \\
\hline Non-smoothing & 214 & 0.2893 & 0.0186 & 0.2734 \\
\hline Smoothing & 261 & 0.1866 & 0.0147 & 0.2384 \\
\hline Diff. bw means & & $0.1027 * * *$ & & \\
\hline t-test & & $(4.3702)$ & & \\
\hline
\end{tabular}

As it can be seen from the table, growth is the factor that differs less than other firm-specific-factors between income-smoothing and non-smoothing observations. This might be because of the fact that growth periods are mostly associated with uncertaintiesas fluctuations, and the volatility in earnings figures might already be expected and tolerated by the analysts and other interested parties, thus executives 
may less pressure on themselves to smooth earnings.

Table-4C GROWTH

\begin{tabular}{l|llll}
\hline \multicolumn{1}{l}{ A- Manufacturing } & & & \\
\hline Groups & Observation & Mean & Std. Error & Std. Dev. \\
\hline Non-smoothing & 981 & 2.2186 & 0.0819 & 2.5678 \\
Smoothing & 439 & 1.8819 & 0.1048 & 2.1961 \\
Diff. in mean & & $0.3367^{* *}$ & & \\
t-test & & $(2.3845)$ & & \\
\hline B- Utility \& Transportation & & & Std. Dev. \\
\hline Group & Observation & Mean & Std. Error & 1.4564 \\
\hline Non-smoothing & 57 & 2.1150 & 0.1929 & 1.3694 \\
Smoothing & 17 & 1.7382 & 0.3321 & \\
Diff. in mean & & 0.3768 & & \\
t-test & & 0.9486 & & Std. Dev. \\
\hline C- Finance & & & & 1.3655 \\
\hline Group & Observation & Mean & Std. Error & 2.3970 \\
\hline Non-smoothing & 214 & 1.2441 & 0.0933 & \\
Smoothing & 261 & 1.5625 & 0.1483 & \\
Diff. in mean & & -0.3184 & & \\
t-test & & $(-1.2189)$ & & \\
\hline
\end{tabular}

The overall results presented in this study shows that the highest percentage of income-smoothing firms operates in finance industry, while the lowest percentage of income-smoothing firms operates in utility and transportation industry with 59.74 and

32.07 respectively. Although manufacturing industry contains the higher number of income-smoothing observation (467) the percentage of incomesmoothing firms consists of $32.07 \%$ of the whole industry. In other words, approximately 1 in 3 observation in manufacturing sector, 1 in 5 observation in utility and transportation sector and 1 in 2 observation in finance sector implement income smoothing practices. Apart from that, firm-specific factors - size, leverage, growth - levels differ between income-smoothing and non-smoothing firms for manufacturing firms, while the mean values of size and leverage differ between income-smoothing and non-smoothing firms for firms operate in finance sector. In detail, mean values of all three firm specific factors are lower for income-smoothing firms in manufacturing industry, while only mean values of size and leverage are 
significantly lower for finance industry. Moreover,none these factors vary across income-smoothing and non-smoothing firms in utility and transportation sector.

\section{Conclusion}

Income smoothing has been practices by the executives as an intentional practice to obtain a less volatile earnings trend. The strategy is composed of two sub strategies. If the earnings is significantly higher than the historical earnings trend, then the income decreasing measures are taken to make period's earnings converge with the historical earnings trend. On the contrary, if the period's earnings is noteworthily lower than the historical earnings trend, then the executives implement the strategies that leads an artificial increase in the earnings figure that ultimately result in converging to the increasing earnings trend. From this point of view, comprehension of the income smoothing practices in a particular industry or a financial market would help to grasp the quality of the announced earnings figure which is an indispensable component of the valuation process.

This study investigated the income smoothing behaviours of the Turkish firms listed in BIST for the period between 2012 to 2019. The income smoothing practices of the firms were detected via the so-called Eckel Model (1981). The results were classified and presented based on the industries that firms operate in, and the firmspecific factors that they have. The industries were classified into the following three sub-categories: manufacturing, utility \& transportation and finance. According to the results, it was found that about 1 in 3 observation in the manufacturing industry, 1 in 5 observation in the utility and transportation sector and 1 in 2 observationin the finance industry practise income smoothing methods between 2012-2019. Besides that, the firm-specific factors are in relation to the income-smoothing practices. The firms involved in income smoothing practices that operate in manufacturing industry are not only smaller, but also low leveraged and they experience low growth comparing with the non-smoothing firms in the same industry. Moreover, income-smoothing firms are smaller and low leveraged in comparison with the non-smoothing firms in the finance sector. Last but not the least, no significant difference was found between the income-smoothing and nonsmoothing companies in terms of firm-specific factors for the utility \& transportation industry.

Income smoothing activities is a promising and a fruitful area for further 
studies. First of all, the topic has been continuing to evolve as the methods that make the executives able to create artificial increases and decreases in earnings evolve. This means that the topic of income smoothing will keep containing points to be discovered. Secondly, a specific study can be carried out solely for emerging markets as these markets has their own characteristics. Firms from emerging markets are expected to grow fast, and such pace in growth may make the firms' executives need less for income smoothing activities as the growth process inherently embody volatility in earnings, which is normally expected and not to be found odd. Lastly, the reasoning behind the relations between firm-specific factors and income smoothing practices need more and deeper investigation. Firms-specific factors and their levels vary in terms of each company. Thus, a comprehensive and detailed investigation regarding the relation between income smoothing and firmspecific factors would shed a new light on the issue. Moreover, there are number of firm-specific factors, other than size, financial leverage and growth. Thus, by increasing the number and variety of the firm-specific factors would make the further studies more elucidator. However, I believe that it would be useful for both the researchers and the readers of the prospect papers if the researchers use large sample-sizes for their studies since the smaller samples make it difficult to draw a comprehensive conclusion. Moreover, it is generally not possible to generalize the results of the small-sampled papers for the developed financial markets. From this point of view, it can be said that the only limitation of this study might stem from the fact that Borsa Istanbul (BIST) is a relatively smaller stock exchange organisation thus, any result of a study using BIST as a sample cannot be generalized to comparatively larger size stockexchanges.

\section{Bibliography}

Akbari, F., Salehi, M. \& Bagherpour Vlashani, M.A. (2019) The Relationship Between Tax Avoidance and Firm Value with Income Smoothing: A Comparison Between Classical and Bayesian Econometric in Multilevel Models, International Journal of Organizational Analysis, 27, 125148.

Bao, B. H. \& Bao, D. H. (2004) Income Smoothing, Earnings Quality and Firm Valuation. Journal of Business Finance \& Accounting, 31, 791-811.

Beidleman, C. R. (1973) Income Smoothing: The Role of Management, Accounting Review, 48, 653-667. 
Bushman, M. R., \& Piotroski, J. D. (2006) Financial Reporting Incentives for Conservative Accounting: The Influence of Legal and Political Institutions, Journal of Accounting and Economics, 42, 107- 148.

Copeland, R. M. (1968) Income Smoothing. Journal of Accounting Research, 6, 101-116.

Defond, M. L., \& Park, C. W. (1997) Smoothing Income in Anticipation of Future Earnings. Journal of Accounting and Economics, 23, 115-139.

Dichev, I. D., \& Skinner, D. J. (2002) Large Sample Evidence on the Debt Covenant Hypothesis. Journal of Accounting Research, 40, 1091-1123.

Eckel, N. (1981) The income smoothing hypothesis revisited. Abacus, $17,28-40$.

Fudenberg, D., \& Tirole, J. (1995) A Theory of Income and Dividend Smoothing Based on Incumbency Rents. Journal of Political Economy, 103, 75-93.

Goel, A. M. \& Thakor, A. V. (2003) Why Do Firms Smooth Earnings? The Journal of Business, 76, 151- 192.

Healy, P. M. (1985). The Effect of Bonus Schemes on Accounting Decisions. Journal of Accounting and Economics, 7, 85-107.

Ibrahim, A.E.A., Abdelfattah, T. \& Hussainey, K. (2020) Artificial and Real Income Smoothing Around Corporate Governance Reforms: Further Evidence from Egypt", Journal of Applied Accounting Research, 21, 701-720.

Lev, B., \& S. Kunitzky. (1974) On the Association Between Smoothing Measures and the Risk of CommonStocks. The Accounting Review, 49, 259270.

Namazi, M. \& Khansalar, E. (2011) An Investigation of The Income Smoothing Behavior of Growth and Value Firms (Case Study: Tehran Stock Exchange Market), International Business Research, 4, 84-93.

Li, S. \& Richie, N. (2016) Income Smoothing and the Cost of Debt, China Journal of Accounting Research,9, 175-190.

Madhogarhia, P., Sutton, N.K., \& Kohers, T. (2009) Earnings Management Practices Among Growth andValue firms, Applied Financial Economics, 19, 1767- 1778. 
Petersen, M. A., \& S. R. Thiagarajan. (2000) Risk Measurement and Hedging: With and WithoutDerivatives. Financial Management, 29, 529.

Richardson, S. A., Sloan, R. G., Soliman, M. T., \& Tuna, I. (2002) Information in Accruals about EarningsPersistence and Future Stock Returns. Working Paper. University of Michigan.

Ronen, J. and Sadan, S. (1981) Smoothing Income Numbers (AddisonWesley).

Sayuni, H. (2016) Determinant of Income Smoothing At Manufacturing Firms Listed On Indonesia Stock Exchange, International Journal of Business and Management Invention, 5, 01-04.

Watts, R. L., \& Zimmerman, J. L. (1990) Positive accounting theory: A Ten-Year Perspective. AccountingReview, 65, 131-156.

White, G. I., Sondhi, A. C., \& Fried, D. (2003) The Analysis and Use of Financial Statements 3rd Ed. JohnWiley \& Sons. 